\title{
The Apparatus Performance of Public Administration in Education and Culture Field at Bone Bolango Regency of Gorontalo Province
}

\author{
Abdul Muhamad \\ Muhammad Ramli \\ Manan Ceylon \\ Abdullah Sindring \\ Department of Public Administration, Universitas Negeri Makassar, \\ Jin. Bonto Langkasa Kampus Gunung Sari Baru, Indonesia \\ Email:abdmuhh@gmail.com
}

Doi:10.5901/mjss.2016.v7n4p

\section{Abstract}

The aims of this research: the first was to analyze the principle of the apparatus performance of public administration in education field at Bone Bolango regency. The second was to analyze the determinant factor of the apparatus performance of public administration in education at national education office of Bone Bolango regency. This research was a qualitative approach using case study. The data collection techniques were interviews and Focus Group Discussions (FGD). The results showed that the groove in the formulation of the apparatus performance of public administration in education field at Bone Bolango regency of Gorontalo has been implemented. It was suitable with the public administration at ministry of education and culture of the Republic of Indonesia and the constitution. The apparatus performance of public administration in education field at the Bone Bolango regency got a good support from the society. However, the society really needs professional apparatus of public administration in education field at Bone Bolango regency. The performance of professional apparatus of public administration in education field was to provide training of personnel knowledge, the mastery of technology in education services to the community, improvement of human resources and the completeness of infrastructure and facilities in education field and also the attitude of bureaucratic structures. They are all factors that affect the successful performance of the apparatus in qualified public administration in education field at Bone Bolango in Gorontalo province.

Keywords: Performance, Apparatus, Public Administration, Education Field.

\section{Introduction}

The apparatus of government as official servants of the State and society have main duties reflected in the implementation of the general duties of governance and establishment and the implementation of services to the public which is called as public administration. The performance of governmental organizations tends to be spotlight recently, especially since there was a more democratic climate in the government. The measurement of success or failure of government instances in conducting duties and functions was objectively difficult. Performance is defined as an expression of ability based on the knowledge, attitudes, skills and motivation to produce something (Fattah, 1999, p. 19).

A new paradigm in the government hinted that government leaders should consider the interests of society and the interests of government organizations, and also to be proactive to the development and needs of the public. Leaders who can empower organizations are leaders who try to understand fully the presence of staff, listening intently what is proposed and desired by subordinates, always have innovative thinking, willing to explain the details of organizational goals to be achieved, providing the opportunity for staff to develop and are willing to train staff to think critically (Shelton, 2002, p. 99).

The quality improvement of human resources was very influential to the results achieved in the quality of national education. A qualified education can create professional and qualified human resources, can also support the development of national establishment in education field. The basic constitution (UUD) 1945, article 31 of 2002 about Education and Culture of Indonesia can be explained as follows: (a) Every citizen has right to get education; (b) Every citizen have to follow elementary education and the government is obliged to pay it; (c) The Government shall manage and organize a national education system that enhances faith and devotion and noble character in order to educate the 
nation governed by law; (d) The State prioritizes education budget of at least $20 \%$ of the State Budget (APBN) and of the budget revenue and expenditure (budget) to meet the needs of national education; (e) The Government shall advance science and technology to uphold values of religious, norms, laws, culture and national unity for the progress of civilization and the welfare of mankind in Indonesia.

There were some problems of apparatus performance of public administration in education field at Bone Bolango regency. The first was the staffing of the teachers in junior high school (SMP) and senior high school (SMA) which is not spread. The last was the lack of teachers which gave effect on the improvement of passing national exams (UN) in high school at national education office of Bone Bolango regency.

The performance of public administration at the Department of Education in the implementation of the national exam (UN) from the academic year 2011/2012, 2012/2013 and 2013/2014 were as follows: (a) the successful of the performance of public administration at department of education and culture in national exam (UN) of junior high school year 2011/2012 academic reach 97\%, junior high school graduation school year 2012/2013 reached 98.9\% and increased by $1.9 \%$, and junior high school graduation year $2013 / 2014$ reached $99.9 \%$ and increased by $2.9 \%$ and yet achieving the target of national examinations (UN) 100\% Junior high school graduation; (b) Performance of public administration department of education and culture in the national exam (UN) of senior high school graduation academic year $2011 / 2012$ reached $98.54 \%$, the national exam (UN) of senior high school graduation academic year 2012/2013 reached $98.32 \%$ and decreased $0.22 \%$, and national exam (UN) of senior high school graduation academic year 2013/2014 reached $99.61 \%$ and increased $1.09 \%$ and has not yet reached the target of national examinations (UN) in $100 \%$ senior high school graduation; and (c) the performance of public administration of education and culture department in vocational school graduation academic year 2011/2012 reached the target of national examinations (UN) with 100\% graduation, the national exam (UN) of vocational school graduation 2012/2013 academic year did not reach $100 \%$ graduation but only reached $98.81 \%$ and decreased $1.19 \%$, and national exam (UN) of vocational school graduation academic year 2013/2014 reached $100 \%$ graduation and increased to $100 \%$. Graduation rates rise and fall of national examinations (UN) in high school and seldom achieve 100\% graduation.

The performance of public administration of education and culture department in annual national exam (UN) junior and senior high school and also vocational school year 2011/2012, 2012/2013 and 2013/2014 were still caused by the lack of teachers, the lack of discipline in implementing public administration of secondary school education , the lack of implementation in training and controlling the performance of supervisors of high school and vocational school, and the lack of monitoring the performance of the principal and teachers in high school and vocational school at national education office of Bone Bolango regency(National and Education Office of Bone Bolango Regency, 2014).

The Reports of Description Accountability (LKPJ) of Regional Head of Bone Bolango in the plenary session of the Regional Representatives Council (DPRD) Bone Bolango Regency were (a) Assessing the performance of the Department of National Education at Bone Bolango regency with red scores because the budget absorption in 2012 of education field was not optimal yet with only $67 \%$ due to the lower absorption of budget specific allocation fund in education field at Bone Bolango regency; (b) Some activities of education field did not reach the target namely the development and learning activities and the construction of a library in Bone Bolango regency (Pou, 2013, p. 20).

The constitution No. 20 of 2003 on National Education System explained about the performance of public administration in the field of education and welfare of teachers. In reality the central government and regional governments still pay less attention to the welfare of teachers especially in the payment of teacher certification. Services Central Government and Local Government in the field of education is the removal of the Teacher in accordance with the needs of local governments, an increase in teacher certification to work as a professional teacher and improve passing the national exam (UN) Department of Education and Culture of Bone Bolango regency.

The aims of this research: the first was to analyze the principle of the apparatus performance of public administration in education field at Bone Bolango regency. The second was to analyze the determinant factor of the apparatus performance of public administration in education at national education office of Bone Bolango regency.

According to the researcher, the problems above need to be assessed academically and the research entitled "The Apparatus Performance of Public Administration in Education and Culture Field at Bone Bolango Regency of Gorontalo Province."

\section{Literature Review}

\subsection{Theory of Bureaucracy and Public Administration}

According to Sedarmayanti $(2009$, p. 67$)$, bureaucracy is a system of governance that civil servants run by laws and 
regulations.

According to Said, (2009, p. 9), the bureaucracy can be divided into two classifications, namely as a process of public administration as well as the structure or function that is static. Bureaucracy as the governance process by adopting a particular system in which there is division of labor. As the structure or function that is static, officials who run the structure commonly referred to as a bureaucrat.

Bureaucrats, officials and administrative staff are always associated with the government and become an important actor in a good state in political affairs, administration and State policy making (Said, 2009, p. 9).

There were seven modern concepts of public service bureaucracy. The first concept was bureaucracy as a rational organization. The second was bureaucracy as organizational inefficiencies. The third was bureaucracy as an authority run by officials. The fourth was bureaucracy as public administration. The fifth was bureaucracy as administration run by officials. The sixth was bureaucracy as an organization and the seventh was bureaucracy as a modern society. The concept of bureaucracy was a concept that is usually used by a control system in the hands of officials who exercise power (Albrow, 2005, p. 109).

According to Tjokroamidjojo, $(1987$, p. 7) administration is a rational cooperation activities, namely the composition and processes of the organization in relation to the authority hierarchically arranged. According to Waldo (1991: 6), said that the orientation of the classical public administration concerning the activities of government in the implementation of political power.

\subsection{The Concept of Apparatus in Public administration at Education Field}

Public administration is a concept that is always associated with the process of fulfilling the needs of people who are characterized by a lack of accountability of service providers, the government apparatus (Grace, 2009, p. 107).

According to Denhardt (2003, p. 27), apparatus in a public servant should be a lot of "hearing" rather than "telling" and serve "rather than" drive / control ".

According to Lovelock (2002, p. 1), administration is defined as an economic activity that creates and delivers benefits to customers in time and place, as a result and action to realize the desired changes in themselves or on behalf of the service recipients.

Public administration and social responsibility in the business of public affairs role in education should be able to serve the interests of social and accountable to the community (Williamson, 2010, p. 370).

According to Kotler $(2003$, p. 1) administration can be defined as an act or performance that creates benefits for customers to realize the desired changes in them or on behalf of the recipient.

Public administration in education is a responsibility of the government apparatus as a servant of the State and public servants. The responsibility is to give satisfaction to the customer, but still frequent abuse of authority by using its power to suppress or force to the public as he wishes without considering his duties as a public servant (Ramli , 2014, p. 11).

\subsection{The Concept of Apparatus Performance}

According to Hasibuan $(2007$, p. 34) performance is a result of work achieved in executing the tasks assigned to him based on skills, experience and sincerity, as well as determined by the time work.

According to Mangkunagara $(2007$, p. 9) performance is the result of the quality and quantity of work achieved by a civil servant in performing their duties in accordance with the duties and responsibilities given to him. Employee performance cannot be separated from the human resources of the organization, resource-driven or run employees play an active role as actors in an effort to achieve organizational goals (Makmur, 2009, p. 47).

Based on the above understanding, that performance is the results achieved by an apparatus according to the measure of professionalism in the execution of work applied in behavior, intelligence and the ability of employees in accordance with the roles, activities and tasks that have been determined.

Public administration performance SK. MenPAN No. 81/1993 were: (a) Easy handling for all concerned; (b) Got a reasonable service; (c) To get the same treatment without favoritism in public service; (d) Got an honest treatment to the public (Dwiyanto, 2004, p. 17).

The main objective of the reform of public administration is to see a tremendous increase in the output of public administration, such as delivery service that is more effective and responsive. This is the driving force behind the reform of public administration (Tarawa, 2001, p. 147). 


\subsection{The Concept of Qualified Apparatus Performance}

The concept of qualified administration was more referring to efforts to provide qualified, efficient and effective services (Rahkmat, 2009, p. 108). The quality of public administration should be determined according to the dimensions set by the government and relevant to the community that continues to grow dynamically in order to meet society's expectations (Idris, 2012).

According to Waluyo, (2007, p. 24) a professional public administration means that public administration which is characterized by a lack of accountability and responsibility from service providers of the government apparatus. According to Tjiptono (2008, p. 88), there are 7 (seven) terms of the quality of public administration. The first, quality is conformance to requirements / demands. The second, quality is the suitability of use. The third, quality is continuous or completed reparation. The fourth, quality is free from defects. The fifth, quality is fulfilling the needs of the public at any time. The sixth, quality is doing everything correctly from the outset and the last, quality is something that can satisfy both the customer.

The decree of Minister of State Apparatus Empowerment No. 63 of 2003 mentioned that there were 10 (ten) performance principles of qualified public administration. The first was simplicity in the public administration. The second was clarity in the public service. The third was certainty of time in the public administration. The fourth was accuracy in the public $\mathrm{s}$ administration. The fifth was security in the public administration. The sixth was responsibility in the public administration. The seventh was completeness of facilities and infrastructure in the public administration. The eighth was the ease of access to public administration. The ninth was discipline courtesy and friendliness in the public administration and the last was the leisure in the public administration (Dwiyanto, 2006, p. 27).

According to Lovelock (1988, p. 203), there were some formulations to measure the quality of public administration as follows:

a) Reliable, the ability of administration unit to create the promised service accurately, promptly, accurately and satisfy for customers.

b) Responsiveness, the will and desire of the staff to help consumers and responsible for the quality of services provided.

c) Assurance (collateral), which guarantees service includes knowledge, skills, courtesy, and trustworthy owned by the staff in providing services.

d) Empathy, the administration personnel provides an ease to have good communication, personal attention and understand the needs of customers.

e) Tangible (direct evidence), that direct evidence of administration in satisfying the customer and the availability of adequate infrastructure and good communication.

Meanwhile, According to Parasuraman and Zeithami (1990, p. 6), there were five dimensions in qualified public administration, namely:

a) Tangibles, which is a factor of physical facilities, equipment or infrastructure, employees owned by a public administration organization.

b) Reliable, intended as an ability to provide services that have been promised to immediately precise, accurate and reliable.

c) Responsiveness, namely the desire of employees to assist customers to provide fast, accurate, responsive.

d) Assurance, which is knowledge, ability and friendliness of employees to be able to generate trust and confidence of customers to the organization.

e) Empathy, which is a concern, sincerity, attention, as well as various facilities in the communication given by the organization and its employees to customer.

\subsection{The Concept of Apparatus Performance Ethics in Public Administration at Education Field}

The concept of ethics and public administration is meant by the ethics of public administration is a practice of public administration delivery (delivery system) which is based on a series of demands behavior (rules of conduct) or a code of ethics that manage "good" things to do or otherwise "bad" things to avoid, (Denhardt, 1984, p. 1)

Public administration ethic is as a way to serve the public by using the habits that contains the values of life and the laws and norms that govern human behavior is considered good (Wicaksono, 2006, p. 5).

Public administration ethics is a form of control of the state administration in implementing what the basic tasks, functions and authority (Siagian, 2006, p. 76).

State administration ethics want attitudes, actions and behaviors said to be good, then in performing basic tasks 
and functions of the authority must rely on the ethics of State administration (Kumorotomo, 2005, p. 15).

According to Bertens $(2000$, p. 7$)$ the differences on the ethical concept of the concept of etiquette concludes that there are three important meaning of public service ethics, namely:

a) Ethics as moral values and moral norms and into the handle for a person or group in society.

b) Ethics as a set of principles of moral values which are often known by the code of conduct.

c) Ethics as a science about good or bad, the so-called moral philosophy.

Providing a framework for revised measurement results in the public administration at education field can advance the discussion of the results of education. This is a model of learning outcomes for public administration in education program to explain the process of how the public administration can add value to the knowledge of individuals, organizations and governments (Newcomer \& Allen, 2008, p. 207-208).

According to (Dewey, 2011, p. 1) education is the process of establishing fundamental abilities intellectually, emotionally toward nature and fellowship. Education were businesses that deliberately chosen to influence and help children with the goal of increasing physical science and morals. It can deliver the children to the highest goal gradually, so the children live a happy life and all what it does become useful to themselves and society (Yunus, 2011, p. 17).

Education is a conscious and deliberate effort to create an atmosphere of learning and the learning process so that learners are actively developing the potential for him to have the spiritual power of religion, self-control, personality, intelligence, good values and skills, needed him and society (Purwanto, 2000, p. 27).

The ethics of apparatus performance in public administration is the implementation of the performance of the apparatus as a servant of the State who work professionally in public administration related to education and services to meet community needs of Bolango Bone regency, Gorontalo province.

\section{Research Methodology}

This research applied a qualitative descriptive study using a case study method. The research location is in the Office of Education and Culture of Bolango Bone regency, Gorontalo province.

Sources of data in this study was a data source that can provide the information that the informants who were representative and has been linked to problems of performance of the apparatus in the public administration in education field to the needs of the community. The first representative was the Head of Education Department. The second was the Head of Primary and Secondary School. The third were two persons from the Head of Section of Education Department. The fourth were three teachers and the last were five education observers.

Secondary data were obtained through records, archives and documents and all forms of information and information related to the problem under study was obtained from the Office of Education and Culture of Bone Bolango Regency.

The focus of the research problem was the performance of the apparatus of public administration in education field by analyzing the principle of reliability, principle of responsiveness, assurance principles, principles of empathy, and the principle of physical evidence in education field of Bone Bolango regency.

In this study, data collection techniques analysis was through the use of in-depth interviews and focus group interview guide. Data validation techniques through extension of observation, increasing the persistence of researchers in the observation and interviews, addition is done crawl data through documentation technique by recording the data available at the site of research related to the research problem (Sugyono, 2010, p. 186).

Conducting research observation systematically through direct surveillance with instrument data related to research problems. The researcher conducted a triangulation approach that combines interviews, observations and secondary data. Focus Group Discussion (FGD) and the adequacy of reference. Data were obtained through in-depth interview to the apparatus, and observations were discussed with others (peers, community leaders). Those were to analyze the negative cases and comparing with reference materials.

Obtained data were analyzed descriptively. According to Milles and Huberman (2003, p. 287) data analysis techniques used in research is as follows: (a) Data reduction is a form of analysis for the sorting process, simplification, sharpening, classify, direct, dispose of unnecessary data, and organizing data, analyze the data in the field of research; (b) Presentation of data is done in this activity data presentation of research results; and, (c) inference or conclusion of verification is thorough and systematic research.

Qualitative research selects by researchers because researchers did the research planning process but the researchers first perform an observation in depth to find the data and facts of performance issues in public service apparatus field of education and culture of Bone Bolango Regency. 


\section{Results and Discussion}

\subsection{The Implementation of the Apparatus Performance of Public Administration in Education and Culture Field at Bone Bolango Regency.}

The principles of the apparatus performance of public administration in education field at Bone Bolango R egency as follows:

a) Reliability administration is as an ability to provide services promised apparatus in accordance with a predetermined time employee time and served fast, precise, accurate and reliable in service of education and culture.

b) Responsiveness administration is the desire of the apparatus in education field to provide rapid, precise and responsive services to the customers and communities in education and culture field.

c) Assurance administration (guarantee) the ability of the apparatus of knowledge in dealing with customer issues and provide a guarantee of compensation resulting from risks and errors of personnel services to the community in education and culture field.

d) Empathy administration (attention) the ability of personnel to implement the approach and assertive and attentive attitudes to the public in education and culture field.

e) Tangibles administration (physical evidence) in education field is the performance of the apparatus to provide physical facilities, equipment and responsibilities of educational services infrastructure that is owned by an organization for the benefit of society (Source Department of Education and Culture, 2014, p. 47).

\subsection{The Performance of Public Administration of Department of Education and Culture in Bone Bolango Regency}

The apparatus performance of qualified public administration in education field was the implementation of the performance of the apparatus as a servant of the State and public servant who works professionally in the field of education of qualified public administration, precise, fast, fair, transparent, credible services. Those services related to education services and the needs of the community at Bone Bolango Regency, Gorontalo Province.

There were 6 (six) apparatus performance and activities program of public administration in education field at Bone Bolango regency, Gorontalo province. The first was the program services for early childhood education $(E C D)$ is the ministry of education to early childhood. The second was the program of compulsory nine-year basic education is compulsory school education services 9 years is further completed primary school secondary school. The third was the secondary education services program is a government program for the service of education junior high school (SMP) and senior high school (SMA). The fourth was non-formal education program is a government program to perform nonformal educational services such as education SDLB, SMPLB, SMALB. The fifth was the program to improve the quality of teachers and government procurement is a teacher certification program to improve the quality of professional teachers in Indonesia. The sixth was educational services management program is a government program to perform management services quality education in order to determine the performance of the teacher, principal and school supervisors in Indonesia (Department of Education and Culture, 2014, p. 64).

\subsection{Determinant factors of public administration performance of Department of Education and Culture at Bone Bolango Regency}

The factors that support the performance of public administration of Department of Education and Culture at Bone Bolango Regency can be explained as follows:

a) The availability of human resources personnel civil servants (PNS) in education and culture field is the ability of apparatus in giving services in education and culture field.

b) Leadership and organizational structure of public administration apparatus in education field is the ability of the head of education department perform functions management of the apparatus in giving public services in education and culture field.

c) Qualified and excellent service in education field is using a professional and excellent, fast, right, fair, reliable, competent, ethical, prosperous, accountable, effective, efficient, conducive and qualified service in education and culture field.

d) The Local Government in giving public administration cooperated with the Office of Education and Culture. The cooperation of apparatus in giving public administration with the local governments was to get the 
success of the work program in education field.

e) The report of performance accountability of government agencies at Education and Culture Office was accountability report of apparatus performance in public administration at education field to local governments. The report was to know the successes and obstacles performance of public administration in the field of education during 3 months, 6 months and 1 year in education and culture field (Department of Education and Culture, 2014, p. 78).

Inhibiting Factors of Apparatus Performance in Public administration at Education and Culture Office of Bone Bolango Regency

a) Lack / limited facilities and infrastructure of the education and culture office

b) There is a lack of human resources at education and culture office

c) Lack of discipline of employees at the education and culture office

d) The existence of competition and echelon positions in the education and culture office

e) The salary of personnel is still low at education and culture office

f) Lack of training and leadership education in apparatus performance at education field (Department of Education and Culture, 2014, p. 127).

\section{Conclusion}

The apparatus performance of public administration at education office of Bone Bolango can be concluded as follows:

a) The implementation of the principles of public administration in education office of Bone Bolango Regency. The principles were still less qualified and not maximized, namely reliability, responsiveness, assurance (guarantee, empathy and tangibles (physical evidence).

b) Principles of reliability were still lack of professional performance in providing easy, fast and precise services, and still less to disseminate educational services to the community.

c) Principle of responsiveness were still lack of professional performance in implement easier, faster and faster services and still many people who queued in education services.

d) The principle of assurance was the performance of the apparatus to guarantee education services if the documents had been lost educational services or errors in the field of educational services to the community.

e) The principle of empathy (sympathy) was the performance of the apparatus which is still unfair in giving services to the community.

f) The principle of tangibles (physical evidence) was the lack of facilities and infrastructure so that performance was still less qualified personnel and budget constraints revenue shopping area (APBD) in education field to the community.

The performance determinant factors of the apparatus in the education office of Bone Bolango are as follows:

a) The availability of human resources personnel in the public service.

b) Leadership and organizational structure still need qualified apparatus performance in giving public administration to the community in education field.

c) Implementation of educational services were less qualified and excellent service to the community in education field.

d) Cooperation with Local Government in the success of public administration is still poor-quality education to the community.

e) Report of performance accountability of government and the performance of public administration were less qualified at education and culture office

Inhibiting factors of the apparatus performance of public administration in education field as follows:

a) The lack of facilities and infrastructure of educational services so that the poor-quality educational services in the education department office

b) The quality of human resources is still low. Number of civil servants (PNS) still dominated with high schools (SMA) who works at the education department office.

c) Lack of discipline of apparatus in educational services so the quality of educational services were still poor.

d) The existence of competition position and echelon apparatus so that less qualified educational services

e) The salary of apparatus was still low so the quality of education services at education and culture department office was also low.

f) Lack of guidance and educational training for the apparatus so the quality of educational services in education and culture field was low. 


\section{References}

Albrow, Martin. (2005). Bureaucracy. Yogyakarta: Tiara Discourse

Anonim. (1984). The ethics of the Public Service. New York: Armonk.

Anonim. (2002). Service Marketing In Asia. Singapore: Prentice Hall Inc.

Anonim. (2006). Methods of Research Administration. Bandung: Alfabeta

Anonim. (2007). Understanding Qualitative Research. Bandung: Alfabeta.

Armadi, Rulam. (2005). Understanding Qualitative Research Methodology. Malang: Malang State University Press

Bertens, K. (2000). Public Service Ethics. Jakarta: PT Gramedia Main Library.

Bungin, Burhan. (2007). Qualitative Research. Jakarta: Prenada Media Group

Denhart, Janet. (2003). The New of Public Service: Serving Not Steering. New York: M.E. Sharpe, Inc.

Dewey. (2011). Introduction to Leadership Education. Jakarta: PT Ghalia Indonesia.

Dwiyanto, Agus. (2005). Public Bureaucracy Reform in Indonesia. Yogyakarta: Center for Population and Policy Studies (CPPS), UGM

Fattah, Nana. (1999). Education Management runway. Bandung: PT. Teens Rosda paper.

Haryono, Sapta. (2009). Methods of Human Resources. Jakarta: Earth Literacy.

Hasan, M.Iqbal. (2002). Research Methodology and Applications. Jakarta: Earth Literacy.

Hasibuan, Malay SP. (2007). Human Resource Management. Jakarta: PT Gramedia.

Idris, Amiruddin., \& Apparatus SKPD. (2012). Performance and Quality Public Services. Jakarta: Rineka Reserved.

Kumorotomo, Wahyudi. (2005). The State Administration Ethics. Jakarta: King Grafindo Persada.

Kotler, Philip. (2003). Marketing Management. New Jersey: Prentice Hall Publishers.

Office of Education. (2014). In the Public Service Sector Education. Gorontalo: Department of Education.

Lovelock. Christopher. (1988). Product Plus: How Competitive Product Service Advantage. New York: Mc. Graw Hill International Editions.

L. Williamson., \& F. Burke. (2010). International Journal of Public Service and Social Responsibility: A Role for Public Affairs in the Undergraduate Business Education. Boston Massachusetts: Suffolk University.

Mangkunagara, A. A. King. (2007). Human Resource Management. Bandung: PT. Young Rosda paper.

Makmur. (2009). Theory and Strategic Management in Government Development. Bandung: PT. Refika Aditama.

Marni, Nisabu. (2014). Performance Public Service Apparatus Department of Education and Culture of Bone Bolango District. Gorontalo: Department of Education and Culture of Bone Bolango District.

Moleong, Lexi J. (2010). Qualitative Research Methodology. Bandung: PT Young Rosdakarya.

Milles et al. (2003). Qualitative Research Methods. Jakarta: Earth Literacy.

Newcomer, K. E., \& Allen, H. (2010). Public Service Education. Journal of Public Affairs Education, Vol. 16 (2), pp. 207-229.

Purwanto, M. Ngalim. (2000). Theoretical Education. Bandung: Rosdakarya.

Parasuraman, Zeithaml., \& Bitner, Mary Jo. (1990). Service Marketing. New York: McGraw Hill Inc.

Pou, Hamim. (2013). Performance Bone District Education Office Bolango Value Red. Gorontalo: Gorontalo Publisher Post.

Robbins, Stephen P. (2005). Organizational Behavior. Jakarta: Salemba Four.

Rahkmat. (2009). Theory of Public Administration and Management. Jakarta: Reader Arif.

Ramli, Muhammad. (2014). Public Service Management Based Humanity. Makassar: Alauddin University Press.

Rijal, Syamsul. (2010). Theory of Motivation and Performance of Employees. Makassar: Fahmis Library.

Sedarmayanti. (2009). Human Resource Management: Reforms and Management of Civil Servants. Bandung: Refika Aditama.

Said, Mas, ud. (2009). In Bureaucratic State. Malang: UMM Press

Siagian, Sondra P. (2006). Human Resource Management. Jakarta: PT. Gramedia.

Sugyono. (2010). Quantitative Approach Educational Research Methods and Qualitative. Bandung: Alfabeta.

Sukardi. (2009). Educational Research Methods. Jakarta: PT Bumi Literacy.

Sutrisno Hadi. (2001). Methodology Research. Yogyakarta: Gadjah Mada University.

Tjiptono, Fandy. (2008). Satisfaction in the Public Service. Jakarta: Salemba Four.

Tjikroamidjojo, Bintoro. (1995). Introduction to Development Administration. Jakarta: LP3ES Indonesia.

Tarawa, I. (2001). Public Reform in Kiribati. A paper presented at the National Center for Development Studies. Kibirati Center: The University of the South Pacific.

Waldo, D. (1991). Public Administration. Jakarta: Earth Literacy.

Waluyo. (2007). Public Management, Concepts, Applications and Implementation in Implementation of Regional Autonomy. Sumedang: Mandar Maju.

Wicaksono Kristian, Widya. (2006). Administration and Government Bureaucracy. Bandung: PT Graha Science.

Yunus, Muhammad. (2011). Management Education. Jakarta: PT Gramedia. 